\title{
Introduction to the 1993 Edition
}

THIS INTRODUCTION serves two major purposes. First, it offers an entrée, for readers less familiar with it, into the literature to which The Origins of the National Recovery Administration belongs. Second, it affords the author the opportunity to take stock of the relevant books and articles that have appeared since the book's original publication. No one has yet offered a full-scale alternative treatment of the story told in this book-namely, that the National Industrial Recovery Act (N.I.R.A.) was chiefly the result of a secular campaign by broad segments of the business community to secure liberalization of antitrust strictures against cartelization 1 - but new research has enhanced and extended many of the elements that appear in the narrative given here. This is true above all of the role played by the central figure of the period in which this story of NRA's gestation is played out, the period between World War I and the onset of the New Deal: Herbert Hoover.

This book belongs to the literature of government-business relations; its specific period, the 1920 s and early '30s. Its interpretations were influenced by the conceptual tools that became available as it was researched and written. My interest in the subject was first engaged during the late 1950s, when it was struck by the glaring incongruity between current business ideological pretensions and the ideological leanings I discovered in reading the business press for the Depression years. During the post-New Deal era, business ideologists had constructed and persuasively broadcast a celebratory portrayal of the American business system. It was a "free enterprise" system, founded on competition and initiative. It was progressive, productive, had served America marvelously in World War II, and was now the source of bountiful prosperity and strength in the Cold War. ${ }^{2}$ It was a time when much of the scholarly world, while not actually endorsing these pretensions, nonetheless was overturning progressive historiography's view of businessmen as greedy monopolists, rehabilitating the "Robber Bar-

${ }^{1}$ Donald R. Brand's Corporatism and the Rule of Law: A Study of The National Recovery Administration (Ithaca: Cornell University Press, 1988) contains much original research, but it is focused on the question of business behavior during the course of the NRA. It gives scant attention to the context and the forces at work when the N.I.R.A. was drafted in 1933.

${ }^{2}$ Francis X. Sutton, Seymour E. Harris, Carl Kaysen, and James Tobin, The American Business Creed (Cambridge: Harvard University Press, 1956). 
viii

ORIGINS OF THE NRA

ons," and finding much to applaud in the contributions of the American business system to the American bounty which, nearly everyone agreed in the '50s, was extensive and unique. ${ }^{3}$

There were, of course, countering intellectual currents. The progressive point of view, which saw recent American history as a kind of dialectic struggle between the power and privilege of entrenched business interests and liberal reformers endeavoring to use the state to counter and balance that power, was still dominant among many leading historians. The viewpoint, though, was increasingly influenced by the pluralist outlook, in which reformers were engaged in establishing the basis for and then conducting a fair fight among interest groups. ${ }^{4} \mathrm{~A}$ stronger antidote to the widely accepted business triumphalism, however, was the impact of C. Wright Mills's The Power Elite, which saw business as the most influential element in an interlocking directorate of businessmen, military leaders, and politicians which controlled America. $^{5}$

Still another antidote was the flowering in the '50s of the literature of micro-economic analysis and of antitrust. This literature revealed the vast gap between the ideal and the real in the performance of the business system and seemed to imply a remarkable propensity on the part of business to violate the frequently proclaimed creed of enterprise and competitiveness. With new sophistication, economists were demonstrating how competitive markets optimized economic welfare, how oligopolistic market structures frustrated optimization, and how better enforcement of the antitrust laws, including the new Celler-Kefauver AntiMerger Act, could improve welfare outcomes. ${ }^{6}$

${ }^{3}$ Allan Nevins, Study in Power: John D. Rockefeller, Industrialist and Philanthropist, 2 vols. (New York: Scribner's, 1953); Ralph and Muriel Hidy, Pioneering in Big Business, 1882-1911 (New York: Harper, 1955); Julius Grodinsky, Jay Gould: His Business Career, 1867-1892 (Philadelphia: University of Pennsylvania Press, 1957); Hal Bridges, "The Robber Baron Concept in American History," Business History Review, 33 (Spring 1958), 1-13; and Edward Kirkland, "The Robber Barons Revisited," American Historical Review, 66 (October 1960), 68-73.

${ }^{4}$ The three great classics of progressive historiography for the Republican era between World War I and the New Deal are William E. Leuchtenburg, The Perils of Prosperity, 1914-1932 (Chicago: The University of Chicago Press, 1958); John D. Hicks, Republican Ascendancy, 1921-1933 (New York: Harper \& Row, 1960); and Arthur M. Schlesinger, Jr., The Crisis of the Old Order, 1919-1933 (Boston: Houghton Mifflin, 1957).

${ }_{5}$ Mills, The Power Elite (New York: Oxford University Press, 1956).

6 Joe S. Bain, Industrial Organization (New York: Wiley, 1959); Karl Kaysen and Donald F. Turner, Antitrust Policy: An Economic and Legal Analysis (Cambridge: Harvard University Press, 1959); George W. Stocking, Workable Competition and Antitrust Policy (Nashville: Vanderbilt University Press, 1961); and Tibor Scitovsky, Welfare and Competition: The Economics of a Fully Employed Economy (Chicago: Irwin, 1951). 
Already made somewhat suspicious of the contemporary business apologia by these influences and chancing to explore as a brief project the origins of the NRA, my interest, as already noted, was piqued by the incongruity of the frequent railings against competition one found in the business press, in the trade journals and newspapers, of the Great Depression years. It was no discovery that business, or some part of it, had wanted, at the bottom of the Depression, something like the NRA, but the demands for antitrust relief, for freedom to cartelize, appeared to go back further, be more extensive and more ideologically complicated than was known. ${ }^{7}$ From there the book began, and as my research proceeded in the archives and the business press, it became the story of a protracted effort on the part of elements in the business community to liberalize the anti-cartel provisions of the antitrust laws. Fluctuating in degree of inclusiveness, this business movement extended from World War I to the New Deal, when it for a time succeeded.

Meanwhile, the subject of government and business was exciting a wave of scholarly interest which has not yet abated. The influences which stimulated this interest were in part similar to or grew out of those I have already described as operating in the late ' $50 \mathrm{~s}$. First there was the lingering influence of the traditional progressive-pluralist interpretation. The increasing attraction of pluralist interpretations of political behavior led many writers to discover rivalry within the business community and complexity in its relations with government. ${ }^{8}$ On another side, however, the debate Mills had initiated in the mid-'50s was taken up with everincreasing vigor by other academics on the left during the '60s. The contemporary issue of whether a "warfare state" had overtaken America and was controlling policy, including the war in Vietnam, ensured an attentive audience for the thesis that America had long since fallen under the domination of the corporations. A series of impressively conceived publications in that decade argued that the corporate elite had secured control of state policy at the beginning of the century and, by persuading liberal reformers of the permanency and necessity of the great corporation as the center of American economic life, had irrevocably foreclosed

${ }^{7}$ Arthur M. Schlesinger's account in The Coming of the New Deal (Boston: Houghton Mifflin, 1959) exaggerates out of all proportion, in my view, the influence of "planning" advocates such as Rexford Tugwell in the background of the NRA, but it nonetheless was a sophisticated and highly nuanced account and a landmark in NRA historiography.

${ }^{8}$ Robert $\mathrm{H}$. Wiebe initiated this emphasis in "Business Disunity and the Progressive Movement, 1901-1914," Mississippi Valley Historical Review, 44 (March 1958), 664-85, and in Businessmen and Reform: A Study of the Progressive Movement (Cambridge: Harvard University Press, 1962). The most important book on business and government in this decade was Ellis Hawley's The New Deal and the Problem of Monopoly: A Study in Economic Ambivalence (Princeton: Princeton University Press, 1966). 
debate on reform options other than those that conformed to the needs of the prevailing corporate structure. All the major political figures and movements, according to this theory, would henceforth defer to the hegemony of the corporation elite; liberals, those seeking to ameliorate social conditions, would act within the confines of "liberal corporatism," shaping and limiting reform to accord with the preferences and needs of the corporate order. ${ }^{9}$

A fresher intellectual influence, however, was the shift in interpretive perspective introduced very late in the ' 50 s and in the ' 60 s by a number of notable historians, above all Sam Hays, Robert Wiebe, and Alfred Chandler, who, drawing upon sociological theory stemming from Weber, demonstrated the utility of a new way of thinking about the behavior and motivation of many of those figures, not the least businessmen, who had promoted change and reform of American policy and institutions. This explanation stressed the great importance in the recent American past of the people who managed, or were linked to the management of, the great bureaucratic organizations that had developed from the last part of the nineteenth century. Organization builders had an ethos and a logic of their own; their values were those of predictability, stability, efficiency, and harmonization of interests. They conducted the world of organizations according to these values, and when they looked outward to society's social and economic problems, saw a broader field for application of these values and modes of problem solving. This "organizational" perspective taught historians to think of organization-building as the leitmotif of early twentieth-century American history, the era when not only business but other segments of society endeavored to erect large organizations. Run by professional managers using bureaucratic and scientific methods, these organizations, and the ideas, goals, and behaviors of those who ran them, deserved to be studied on their

9 This term, "liberal corporatism," will be used consistently hereafter to designate the point of view explained in this paragraph.

An early influential statement was made by Martin J. Sklar in "Woodrow Wilson and the Political Economy of Modern United States Liberalism," Studies on the Left, 1 (1960), 17-47. Also very influential were Gabriel Kolko, The Triumph of Conservatism: A Reinterpretation of American History, 1900-1916 (New York: Free Press, 1963) and James Weinstein, The Corporate Ideal in the Liberal State, 19001918 (Boston: Beacon, 1968). Another important title is A New History of Leviathan: Essays on the Rise of the American Corporate State, edd. Ronald Radosh and Murray N. Rothbard (New York: Dutton, 1972). For an interesting review, and rebuttal, of their views, see Alan L. Seltzer, "Woodrow Wilson as 'CorporateLiberal': Toward a Reconsideration of Left Revisionist Historiography," Western Political Quarterly, 30 (June 1977), 183-212.

An excellent study of origins and influences for the radical history produced in the '60s is Irwin Unger's The Movement: A History of the American New Left, 1959_ 1972 (New York: Dodd, Mead, 1974). 
own terms rather than judgmentally. Thus, Chandler emphasized that productivity and efficiency were a major rationale of corporation builders; and Wiebe argued that the corporation elite's interventions in the political realm were intended not to stifle reform but to create a version of reform which used bureaucratic and scientific methods, the methods of the corporate world, to achieve social stability and harmony. ${ }^{10}$

In the later ' 60 s and early ' 70 s, the interpretive modality stemming from the "organizational" outlook proved more attractive among working historians than the one stemming from the New Left. As research proceeded, an interesting new interpretive concept arising out of the "organizational" perspective appeared; this held that an important element within the business elite, who came by this branch of inquiry to be styled "corporate liberals," had, at least at times-and one important relevant epoch was the era from World War I to the New Deal-sought to create a favorable environment for business and to promote a stable and progressive economy, through non-statist modes of action. These modes were, above all, those of urging and implementing, through volunteerism, temporary control structures during emergencies (such as World War I) and cooperative organization, within business and between business and government, to overcome economic and social problems. ${ }^{11}$

${ }^{10}$ Alfred D. Chandler, Jr., offered a pioneering explanation why, other than to seek monopoly, business organizations might push for very large size in "The Beginnings of 'Big Business' in American Industry," Business History Review, 33 (Spring 1959), 1-31. He pursued this theme of the dynamics of large business organizations in Strategy and Structure: Chapters in the History of the Industrial Enterprise (Cambridge: The MIT Press, 1962); Giant Enterprise: Ford, General Motors, and the Automobile Industry (New York: Harcourt, Brace, World, 1964); with Louis Galambos, "The Development of Large Scale Economic Organizations in Modern America," Journal of Economic History, 30 (March 1970), 201-17, and in numerous subsequent publications; the capstone was The Visible Hand: The Managerial Revolution in American Business (Cambridge: Harvard University Press, 1977). Robert Wiebe's most influential work was The Search for Order, 1877-1920 (New York: Hill \& Wang, 1967). Sam Hays undermined progressive historiography in The Response to Industrialism, 1885-1914 (Chicago: The University of Chicago Press, 1957) and brilliantly demonstrated the leading role the ethos of managerialism played in the development of progressive era reform in Conservation and the Gospel of Efficiency: The Progressive Conservation Movement, 1890-1920 (Cambridge: Harvard University Press, 1959).

For more extensive reviews of the origins of the "organizational" outlook, see Louis Galambos' two articles: "The Emerging Organizational Synthesis in Modern American History," Business History Review, 44 (Autumn 1970), 279-90, and "Technology, Political Economy, and Professionalization: Central Themes of the Organizational Synthesis," ibid., 57 (Winter 1983), 471-93. See also Robert D. Cuff, "American Historians and the 'Organizational Factor,'" Canadian Review of American Studies, 4 (Spring 1973), 19-31.

${ }^{11}$ The term, "corporate liberal," will be used hereafter to designate the subjects of the literature described in this paragraph. 
Recognition of and emphasis upon this kind of business behavior stemmed in part from a renewed interest in the career and ideas of Herbert Hoover, occasioned by the opening of the Hoover Presidential Library in 1966, for Hoover, it was found, was the chief protagonist of "corporate liberalism." Long before that term was coined, reinterpretation of Hoover had begun. The myth that laissez-faire attitudes reigned among businessmen and the Republican leaders of the 1920s prevailed in the work of some historians until the 1960s, although as early as 1952 Eric Goldman perceptively explained Hoover's ideas about "associational activities" as a kind of reform ideology. In the early '60s several important treatments of Hoover's career appeared which rescued him from accusations of laissez-faire do-nothingism. His repeated efforts to protect wages and promote spending and lending through voluntary cooperation and mobilization of the industrial and banking sectors were recognized and the ideas which shaped, and limited, his activism, partially illuminated. ${ }^{12}$ Not until the later '60s, however, did historians, with the advantage of the "organizational" perspective and the availability of new sources, begin to uncover the extent to which Hoover had in the '20s, as well as during his presidency, been at the center of, but not

Important titles from this period include: Louis Galambos, Competition and Cooperation: The Emergence of a National Trade Association (Baltimore: The Johns Hopkins University Press, 1966); Robert Cuff's many articles, especially "A 'Dollara-Year Man' in Government: George N. Peek and the War Industries Board," Business History Review, 41 (Winter 1967), 404-20; "Woodrow Wilson and Business-Government Relations During World War I,' Review of Politics, 31 (July 1969), 385-407; with Melvin Urofsky, "The Steel Industry and Price-Fixing During World War I," Business History Review, 44 (Autumn 1970), 291-306; and The War Industries Board: Business-Government Relations During World War I (Baltimore: The Johns Hopkins University Press, 1973); Melvin Urofsky, Big Steel and the Wilson Administration (Columbus: Ohio State University Press, 1969); the author's two articles, "The War Industries Board and the Antitrust Question in November, 1918," Journal of American History, 52 (June 1965), 59-74, and 'Business, Antitrust Policy, and the Industrial Board of the Department of Commerce, 1919," Business History Review, 42 (Spring 1968), 1-23; and Joan Hoff Wilson, American Business and Foreign Policy, 1920-1933 (Lexington: The University Press of Kentucky, 1971).

Two very useful surveys of this "corporate liberal" literature are Ellis Hawley's "'The Discovery and Study of a 'Corporate Liberalism,'” Business History Review, 52 (Autumn 1978), 309-20, and Louis Galambos' "Technology, Political Economy, and Professionalization," esp. 478-91. Together these two articles provide an extensive bibliography for the period through 1982 .

${ }_{12}$ Eric Goldman, Rendezvous with Destiny (New York: Knopf, 1952), pp. 30673; H. G. Warren, Herbert Hoover and the Great Depression (New York: Oxford University Press, 1959); Joseph Brandes, Herbert Hoover and Economic Diplomacy (Pittsburgh: University of Pittsburgh Press, 1962); Carl Degler, "The Ordeal of Herbert Hoover," Yale Review, 52 (Summer 1963), 563-83; Albert U. Romasco, The Poverty of Abundance: Hoover, the Nation, and the Depression (New York: Oxford University Press, 1965). 
the only important leader in, a surge of "corporate liberal" activism which had attracted a broad participation. ${ }^{13}$

It seems in order at this point to offer an outline of The Origins and an account of its themes and conclusions. This will suggest, I think, that all the perspectives outlined in the preceding paragraphs have left their mark and influence upon a book whose underlying approach is nonetheless pluralistic; it will also prepare the ground for a review of the subsequently published literature and its bearing on those conclusions. To begin: this volume offers an explanation of the origins of one of the most interesting episodes in the history of American political economy, the National Recovery Administration of 1933-1935. This explanation can be stated simply and briefly as follows: The NRA represented the climax of a business crusade to liberalize antitrust restrictions on cartel practices. This business crusade, or movement, began as World War I ended and extended through the ' 20 s, grew in intensity during the early Depression years of the Hoover presidency, and triumphed in 1933 by persuading the nation, and the new administration of Franklin Roosevelt, that a cartelized economy offered a way out of the Depression.

Most of the book is an account of this long business movement to reduce or eliminate the severe prohibitions antitrust policy had for many years placed upon so-called loose combinations (cartel agreements) that restrain competition among independent firms. At the same time, it recounts the history of antitrust policy itself during the period, of how it influenced and in turn was influenced by the business crusade for liberalization. This movement for antitrust relaxation was somewhat distinct from but intertwined with yet a third relevant element in business-government relations, the trade association movement which burgeoned during the '20s, sponsored and encouraged by the Republican administrations, especially by Herbert Hoover and his Commerce Department. An ideology had gradually evolved and now emerged fullbodied under Hoover's leadership, which enveloped cooperative practices among business firms in the same industry, and between them and government, in a mantle, not merely of respectability, but also of devotion to the economic commonweal. In the immediate postwar era many business groups, confident from the widespread public perception that industrial mobilization had been enormously successful and embold-

${ }^{13}$ Ellis Hawley, "Secretary Hoover and the Bituminous Coal Problem,' Business History Review, 42 (Autumn 1968), 253-70; the essays by Hawley and this author in Herbert Hoover and the Crisis of American Capitalism, edd. J. Joseph Huthmacher and Warren I. Susman (Cambridge: Schenkman, 1973), pp. 3-34; Carolyn Grin, "The Unemployment Conference of 1921: An Experiment in National Cooperative Planning,"' Mid-America, 55 (April 1973), 83-107; Peri E. Arnold, “Herbert Hoover and the Continuity of American Public Policy,' Public Policy, 20 (Fall 1972), 52544. 
ened by the wartime suspension of the antitrust laws, had outspokenly demanded their permanent relaxation. But when the postwar economy soured and social conflict mounted, so did criticism of overt cartel practices, price-fixing, and the like. Critics found problematic, at best, a range of practices that trade association spokesmen claimed were blameless. Questioned especially were the "open price" practices hundreds of associations had adopted. Harding's Attorney General, Harry Daugherty, responding to public outrage, ordered his Antitrust Division to attack such associations in court and, between 1921 and 1924, in general sought to set rather narrow limits on the cooperative practices in which trade associations could engage. Hoover opposed him and was vindicated in 1925, after Coolidge on other grounds had rid the administration of Daugherty, by the Supreme Court's ruling in Maple Flooring that trade association practices which did not directly fix prices or allocate market shares, or inevitably tend to that result, were not in themselves illegal. With this victory in hand, many trade associations as well as many of the broader, more inclusive business organizations, now pushed hard for further and more fundamental antitrust relaxation. Abetted by Coolidge appointees, the Federal Trade Commission endorsed industry codes which supposedly were designed to define fair competitive practices but actually were intended to restrict competition. Meanwhile, Coolidge's Justice Department allowed associations to experiment with practices which went beyond what the Supreme Court had granted. A movement for antitrust revision now gathered strength but was divided over strategy. Some business groups believed administrative relaxation would lead to eventual judicial antitrust liberalization and feared an open attack on the law might stimulate political opposition. Other groups openly challenged the antitrust laws and initiated a movement to secure legislative revision. Severe economic pressure after the downturn of 1929 gradually pushed a wide range of influential trade associations as well as the major business organizations toward the more radical position. By 1931 the Chamber of Commerce of the United States had held a referendum on and approved a plan which coupled antitrust liberalization with the promise of economic recovery and worker benefits, a proposal frequently repeated by others over the next year.

Hoover's position as this revision movement gathered strength during the later 1920s was somewhat anomalous. It seems clear that he felt cooperative business practices should be judged more according to necessity and effect than by strict formalisms such as the per se rule that overt agreements on price or market share were always illegal. But he refused to lend himself to the revisionist movement because he feared the economic consequences of the wholesale abandonment of the discipline such rules imposed and also because he feared the political consequences of such a step. Indeed, after becoming president, Hoover 
approved his attorney general's crackdown on trade association evasion of the antitrust laws and, when leaders of the revisionist movement asked for his support, he bitterly denounced their program.

The revisionists hoped to succeed with the new president but at first were disappointed as Roosevelt was disinclined to include the revisionist program in the legislative program of the early New Deal. By April, however, demands upon Roosevelt to do something dramatic and direct to promote industrial recovery had grown too strong to resist. Business spokesmen hastily repackaged their long-sought goal of antitrust relaxation, promoting it as a way to quickstart the economy. Pressured thus by organized business, and seeking to avoid or blunt demands from both labor leaders and their political allies for a thirty-hour work week, and from influential Senate liberals to resort to big public works spending, Roosevelt ordered his aides to bring all these proposals together into a recovery measure. Business spokesmen dominated the drafting process and secured a recovery measure which, by suspending the antitrust laws, would legalize cartel practices. Although the National Industrial Recovery Act of June 1933 was a compromise measure, giving something to labor, spenders, and business, it yielded most to the businessmen, who would dominate the policies and practices of the National Recovery Administration.

The conceptual influences already alluded to which initiated my research remain clearly in evidence in the completed Origins. A judgmental tone can be perceived, for the author thought of the antitrust tradition, the policy of maintaining competitive markets, as a central, vital, broadly accepted, and essential component of American political economy. ${ }^{14}$ In this light, the business movement to substitute a pro-cartelization policy constitutes overreaching, an attempt to grab market power and privilege. The impact of the New Left's "corporatist"' analysis during the 1960s probably encouraged this judgmental proclivity somewhat, even though, of course, this account clearly rejects the fundamental thesis of the New Left view that the corporate world had secured control of public policy in the pre-war years of the new century. For the account here seeks to demonstrate throughout that the battle over cartel policy during the Republican era before the New Deal was real and hard fought. Moreover, the businessmen found here do not behave much like the confident and united members of a hegemonic class, for they are deeply divided over strategy for securing tighter control over the market and even over whether they should seek formal control of it at all. Nonetheless, it does

${ }_{14}$ See the excellent recent account of American antitrust history, set in counterpoint to British policy toward trusts and cartels, in Tony Freyer's Regulating Big Business: Antitrust in Great Britain and America, 1880-1990 (New York: Cambridge University Press, 1992). Synthesizing an enormous literature, Freyer demonstrates how substantial the impact of antitrust has been on the American industrial system. 
become clear that, by one means or another, a very high proportion of them did seek that control and that when conditions became bad enough most of them were ready to support, actively or at least acquiescently, the political struggle to secure formal control. The battle to secure this control was, moreover, fought on ideological grounds; that is, the revisionists claimed that a cartelized and "rationalized" industrial order would be more stable and progressive than the more turbulent, competition-plagued order. Had businessmen succeeded somehow in popularizing this cartelization ideology and in tailoring NRA policies entirely in accord with their own plans, which minimized the role of either labor or public oversight, then they might indeed have become something like a hegemonic class. Thus, with respect to political economic dispositions, there are resonances between the behavior of the business class as portrayed here and in the "liberal corporatism" thesis. But, as mentioned previously, the battle over ideology and policy fought here between business and other forces could be conceptualized only in pluralistic terms and the likelihood of ultimate winners was remote.

The "corporate liberal" perspective also influenced the conceptualizations that shape this book. The new conception of Hoover is clearly in evidence. A major component of Hoover's activism, as already explained, was the trade association programs his Department of Commerce sponsored, and they receive substantial attention. Hoover appears throughout as pursuing "corporate liberal" strategies, seeking reforms while avoiding the extremes of statism or overweening corporatism.

Research on Hoover's ideas and initiatives has proceeded vigorously since the mid-'70s, for both the Commerce and the presidential years. The economic problems of the past two decades, first stagflation, then lagging productivity and efficiency, have provoked calls for an "industrial policy" based on government-business partnership. Historians have sought to discover and elucidate historical antecedents for cooperative macro- and micro-management of the kind contemporaries were demanding. Ellis Hawley has led the way in this research effort, offering a convincing case that Hoover's thought and work are best conceived as a genuine alternative to liberal reform thought and methods. He has explored the relevance of Hoover's corporatist program for proposals widely heard in the late 1970 s and in the '80s for indicative planning and private-public partnership arrangements. Hoover's corporatism rested upon the premise that, without resorting to further regulation and control by the state, there existed a way to introduce more rationality and predictability into capitalism, to plan for and achieve social-economic amelioration. The keys were voluntary organization, generation and dissemination of appropriate information, and exercise of moral suasion by the organizations to obtain cooperation from individual firms. The information needed would be generated by the voluntary groups them- 
selves, with the aid of the government, and also by more centralized bodies such as economic research agencies. Properly informed and advised, the individual businessman would act rationally, avoid "overproduction," adopt cost-saving practices, and follow progressive labor practices. ${ }^{15}$

is Hawley's extensive work includes: "Herbert Hoover and American Corporatism, 1929-1933," in The Hoover Presidency: A Reappraisal, edd. Martin Fausold and George Mazuzan (Albany: State University of New York Press, 1974), pp. 10119; "Herbert Hoover, the Commerce Secretariat, and the Vision of an 'Associative State,' 1921-1928,' Journal of American History, 61 (June 1974), 116-40; “'Herbert Hoover and Economic Stabilization, 1921-1922," in Herbert Hoover as Secretary of Commerce: Studies in New Era Thought and Practice, ed. Ellis Hawley (Iowa City: University of Iowa Press, 1981), pp. 43-77; “"Three Facets of Hooverian Associationalism: Lumber, Aviation, and the Movies, 1921-1930," in Regulation in Perspective: Historical Essays, ed. Thomas K. McCraw (Cambridge: Harvard Graduate School of Business Administration, 1981), pp. 95-123; "Neo-Institutional History and the Understanding of Herbert Hoover," in Understanding Herbert Hoover: Ten Perspectives, ed. Lee Nash (Stanford: Hoover Institution Press, 1987), pp. 65-84; “" "Industrial Policy' in the 1920's and 1930's," in The Politics of Industrial Policy, edd. C. Barfield and W. Schambra (Washington, D.C.: American Enterprise Institute, 1986), pp. 63-86; "Herbert Hoover and the Sherman Act, 1921-1933: An Early Phase of a Continuing Issue,"' Iowa Law Review, 74 (July 1989), 1067-1104.

Robert H. Zieger, "Herbert Hoover: A Reinterpretation," American Historical Review, 81 (October 1976), 800-10, offers a review of new Hoover literature through the mid-'70s; a later such review is Ellis Hawley's "Herbert Hoover and Modern American History: Fifty Years After," in Herbert Hoover Reassessed, Sen. Doc. 96-63, 96th Cong., 2nd sess. (Washington, D.C.: U.S. Government Printing Office, 1981), pp. 449-69; this last essay is extensively updated in Herbert Hoover and the Historians, ed. Mark M. Dodge (West Branch: Herbert Hoover Presidential Library Association, 1989), pp. 1-37. Also useful and very recent is the bibliography in the second edition of Hawley's The Great War and the Search for a Modern Order: A History of the American People and Their Institutions, 1917-1933 (New York: St. Martin's, 1992).

Other recent major works that illuminate Hoover's corporatist focus or other dimensions of his activities are: Guy Alchon, The Invisible Hand of Planning: Capitalism, Social Science, and the State in the 1920's (Princeton: Princeton University Press, 1985), which shows how Hoover organized private-public planning for macro-economic stability during the '20s; James L. Guth, "Herbert Hoover, the U.S. Food Administration, and the Dairy Industry, 1917-1918,' Business History Review, 55 (Summer 1981), 170-87; Robert D. Cuff, "Herbert Hoover, the Ideology of Voluntarism, and War Organization During the Great War," Journal of American History, 64 (September 1977), 358-72, and "The Dilemmas of Voluntarism: Hoover and the Pork-Packing Agreement of 1917-1919,' Agricultural History, 53 (October 1979), 727-47; Gary H. Koersalman, "Secretary Hoover and National Farm Policy: Problems of Leadership," Agricultural History, 51 (April 1977), 378-95; Joan Hoff Wilson, "Hoover's Agricultural Policies, 1921-1928," ibid., 335-61, and Herbert Hoover: Forgotten Progressive (Boston: Little, Brown, 1975); Robert H. Zieger, "Herbert Hoover, the Wage-Earner and the 'New Economic System,' 1919-1929," Business History Review, 51 (Summer 1977), 161-89; David Burner, Herbert Hoover: A Public Life (New York: Knopf, 1978); James S. Olson, Herbert Hoover and the 
xviii

ORIGINS OF THE NRA

But this book is inclined to treat the "corporate liberals" of the business world with somewhat more skepticism than it treats Hoover. The literature has, it is true, clearly established that "corporate liberal" ideas and modes of action were widespread among those who served the corporations. ${ }^{16}$ That this activity was self-serving seems plain enough, though it is an aspect most writers have not emphasized. A major thesis of "corporate liberalism," after all, was that most of the serious economic and social problems could be solved by cooperation among businessmen, and the need for state activity thus obviated. Industrialists, from the elite figures who controlled General Electric and the other corporate giants and who figured so prominently in social-economic betterment projects, to the proprietors of humble mills and factories, necessarily understood that survival of a relatively unfettered capitalism depended upon continued public belief that business was endeavoring to maintain a successful economy and actually succeeding in doing so. Thus they often were disposed to support cooperative programs. Those who advocated cartelization consistently emphasized its public benefits

Reconstruction Finance Corporation, 1931-1933 (Ames: Iowa State University Press, 1977); Martin L. Fausold, The Presidency of Herbert Hoover (Lawrence: University Press of Kansas, 1985); William J. Barber, From New Era to New Deal: Herbert Hoover, the Economists, and American Economic Policy, 1921-1933 (New York: Cambridge University Press, 1985); Donald J. Lisio, Hoover, Blacks, and LilyWhites: A Study of Southern Strategies (Chapel Hill: The University of North Carolina Press, 1985); Herbert Hoover and the Republican Era: A Reconsideration, edd. Carl Krog and William R. Tanner (Lanham, Md.: University Press of America, 1984); Patrick D. Reagan, "From Depression to Depression: Hooverian National Planning, 1921-1933," Mid-America, 70 (January 1988), 35-60; and Fred A. Bjornstad, "A Revolution in Ideas and Methods: The Construction Industry and SocioEconomic Planning in the United States, 1915-1933,"' (Ph.D. diss., University of Iowa, 1991).

16 Most of the items in note 15 are also relevant here. Other essential titles appearing since the mid-1970s dealing with business and government and business participation in cooperative and volunteeristic programs for economic regulation or improvement include: Burton I. Kaufman, Efficiency and Expansion: Foreign Trade Organization in the Wilson Administration, 1913-1921 (Westport, Conn.: Greenwood, 1974); Kim McQuaid, "Henry S. Dennison and the 'Science' of Industrial Reform, 1900-1950," American Journal of Economics and Sociology, 36 (January 1977), 79-98; idem, "Corporate Liberalism in the American Business Community, 1920-1940," Business History Review, 52 (Autumn 1978), 342-68; idem, "Young, Swope, and General Electric's 'New Capitalism': A Study in Corporate Liberalism," American Journal of Economics and Sociology, 36 (July 1979), 323-34; idem, Big Business and Presidential Power: From FDR to Reagan (New York: Morrow, 1982); Robert M. Collins, The Business Response to Keynes, 1929-1964 (New York: Columbia University Press, 1981); Michael Hogan, Informal Entente: The Private Structure of Cooperation in Anglo-American Economic Diplomacy, 1918-1928 (Columbia: University of Missouri Press, 1977); and Valerie Jean Conner, The National War Labor Board: Stability, Social Justice, and the Voluntary State (Chapel Hill: The University of North Carolina Press, 1983). 
and no doubt believed it would enable them to deliver, as they claimed, on economic stabilization, productivity gains, and higher worker benefits. But if cartelization was not an option, other, less thoroughgoing modes of cooperative behavior were available and could be used, for what they were worth. Additionally, there was the "welfare capitalism" option, in which the corporation provided benefits which workers might otherwise seek through unions or the state. ${ }^{17}$ Both options offered some hope of effecting economic stabilization and improvement, and both reduced the likelihood of demands for expansion of the state or trade unionism.

To conclude that the "corporate liberal" ideologists had in mind protection of the reigning industrial structure and the existing distribution of social and economic power appears to be a safe and not very startling conclusion. In the hands of the cartelization advocates, the ideology actually goes further and serves to strengthen and expand that distribution in favor of the capitalists. Proponents of the sort of cooperative practices Hoover encouraged, practices which supposedly made market-driven capitalism more efficient and rational, less likely to "overproduce," and so on, could plausibly claim that private and public interests alike were reconciled, were served, by what they advocated. But to insist, as the revisionists so frequently did, upon the right to practice an unregulated (except by "self-regulation") cartelization is to demand what is difficult to reconcile with public-regarding pretensions.

By the time Hoover left the Commerce Department to run for president, he and other leading "corporate liberals" had convinced themselves that it was this planning strategy which had ushered in the "New Era," the long period of economic growth and stability of the preceding years. ${ }^{18}$ The coming of the Great Depression soon would sorely disappoint this conviction, however, and the failure of these same methods to stop or reverse the downturn of the economy after 1929 made them appear bankrupt, and they were largely lost to society's memory.

How effective the Hoover program was, to what extent, during the era of prosperity, it had any measurable impact upon economic behavior and results, is problematic. Several recent writers have shown how illequipped the program was to solve the more intractable economic problems of the period, instability in the "sick" and waste in certain highly competitive natural resource industries. ${ }^{19}$

17 Stuart D. Brandes, American Welfare Capitalism, 1880-1940 (Chicago: The University of Chicago Press, 1976), and Edward Berkowitz and Kim McQuaid, Creating the Welfare State: The Political Economy of Twentieth-Century Reform (New York: Praeger, 1988), esp. chap. 3, "An Atmosphere of Organization: The Rise of Welfare Capitalism, 1910-1930.'

18 Alchon, Invisible Hand, pp. 129-30.

19 David E. Hamilton, From New Day to New Deal: American Farm Policy from Hoover to Roosevelt, 1928-1933 (Chapel Hill: The University of North Carolina 
The antitrust revisionists, of course, especially during the Depression, linked their cause with this vision of prosperity and stability through "self-regulation." But Hoover consistently rejected this linkage, believing, as I argue, that wholesale cartelization would remove the incentive to progress, stifle the individualism he treasured, and inevitably invite expansion of state regulation. Nevertheless, his relentless promotion of the concept that economic stabilization was within the nation's grasp unquestionably broadened the credibility and public acceptance of the idea. Hoover preached stabilization through uncoerced cooperation, through uniform behavior arising from voluntary adherence to planning designs. But his efforts no doubt did much to create the atmosphere in which a more full-blooded regulation of behavior, coerced adherence to cartel prescriptions, would become politically plausible. Though this irony is recognized in The Origins, perhaps it deserved fuller consideration.

Press, 1991); James P. Johnson, The Politics of Soft Coal: The Bituminous Industry from World War I Through the New Deal (Urbana: University of Illinois Press, 1979); William G. Robbins, "Voluntary Cooperation vs. Regulatory Paternalism: The Lumber Trade in the 1920's," Business History Review, 56 (Autumn 1982), 358-79; and Kendrick Clements, "Herbert Hoover and Conservation, 1921-33," American Historical Review, 89 (February 1984), 67-88. 